\title{
FLUID ORGANIZING OF WORK IN THE UBIQUITOUS INFORMATION ENVIRONMENT
}

\author{
Masao Kakihara \\ Kwansei Gakuin University \\ Hyogo, Japan
}

\begin{abstract}
The strong trend of miniaturization and personalization of computing devices that continues in our everyday lives has become inseparably linked to the various services and functions these technological artifacts offer. Mobile workers can do their jobs, not just in formal office space, but in locations as varied as hotels and train stations. These workers are actively utilizing various ICTS in their highly mobile work practices. This paper explores an emerging pattern of work practice in the ubiquitous information environment, namely, fluid organizing of work. In rapidly changing businesses such as media, entertainment, and ICT-related areas, an increasing number of workers perform their jobs independently and bring their distinct skills and expertise to organizations on an ad hoc basis. Since business activities are increasingly knowledge-intensive, the importance of effective utilization of external professional workers is increasingly important as well. Such a pattern of organizing work practice has blurred the formal boundaries of organizations. This paper addresses structural changes of those work practices, particularly in the context of mobile professional work, and the technological impacts on those changes. The paper concludes by proposing that in order to appreciate the emerging pattern of work practice in today's ubiquitous information environment, we should take seriously the fluid perspective of work and organization.
\end{abstract}

Keywords Mobile work, professional, work practice, ICT

\section{INTRODUCTION}

In the last two decades, we have seen the rapid diffusion of information and communication technologies (ICTs) into all levels of our social lives. The strong trend 
of miniaturization and personalization of computing devices that continues in our everyday lives has become inseparably linked to the various services and functions these technological artifacts offer. The mobile phone, for example, was first developed and utilized as a consumer product rather than a business service. A number of innovative firms are adopting ICTs for restructuring their business processes and organizational forms. Wireless communication services and applications support mobile workers doing their jobs at various places, not just formal office spaces, but locations such as hotels and train stations as well. The Internet-based technological environment available today, offering ubiquitous accessibility to a broad range of information, serves as a critical foundation for mobile work practices.

This paper tries to explore an emerging pattern of work practice in the ubiquitous information environment, namely, fluid organizing of work. In order to cope with today's turbulent business environment, firms are flexibly mobilizing human resources outside formal organizational boundaries. Outsourcing has become an important strategic option for efficient and effective management, particularly in rapidly changing businesses such as media, entertainment, and ICT-related areas. An increasing number of workers perform their jobs independently and bring their distinct skills and expertise to organizations on an ad hoc basis. Since business activities are increasingly knowledge intensive, the importance of effective utilization of external professional workers is increasing as well. Such a pattern of organizing work practice has blurred the formal boundaries of organizations. This paper addresses structural changes of work practices, particularly in the context of mobile professional work, and the technological impacts on those changes.

\section{MOBILE PROFESSIONAL WORK}

As Schön (1983) argues, professionals have become "essential to the very functioning of our society" (p. 3). Among the oldest professionals would be the clergy and teachers, although they might not have been called or even recognized as professionals at the time. Architects also have a long history of contributing to society as professionals with their expertise of designing and constructing buildings. However, in contemporary society, we recognize more diversity in professionals, including accountants, designers and artists, writers, doctors and nurses, engineers, lawyers, pharmacists, psychologists, counselors, social workers, scientists, librarians, professors, urban planners, and so on.

The existing research has tended to study professionals only within organizations, private or public. As a result, professionals working independently have been largely neglected in contemporary research on professional work. Obviously, most of the "modern" professionals are employed within organizations. As Whalley and Barley (1997) argue, the need for the professionals' expertise was "created" in response to changes of inner conditions of the firms. However, in the light of today's turbulent business environments, addressing only professionals inside the organizational structure clearly does not suffice. In fact, during the last two decades, we have seen a rapid growth of workers who are independent of a formal organization and, in many cases, do their jobs on a freelance or contract basis, establishing ongoing relationships with 
several different client firms (Segal and Sullivan 1995, 1997). Most of them are knowledge-based rather than material-based professionals such as consultants, designers, writers, journalists and planners of various kinds (Meager 1992). Their livelihood depends on selling their own distinct skills, knowledge, and/or tangible and intangible products to firms.

The emergence and rapid growth of such post-modern professionals, freed from conventional employment relationships, is becoming a critical factor in contemporary business environments, especially in knowledge-intensive sectors. Yet surprisingly little research has been done on such post-modern professionals and their work practices, which are not bounded by formal organizational structures, rules, and constraints but play critical strategic roles in organizational contexts.

Among the notable exceptions is Malone and Laubacher's (1998) work. Seeing the success of the Linux open source community, the emergence of virtual companies, the rise of outsourcing and telecommuting, and the proliferation of freelance and temporary workers, they argue

The fundamental unit of such an economy is not the corporation but the individual. Tasks aren't assigned and controlled through a stable chain of management but rather are carried out autonomously by independent contractors. These electronically connected freelancers-e-lancers-join together into fluid and temporary networks to produce and sell goods and services (p. 146).

This kind of independent professional workers, e-lancers in their words, can be seen at the forefront of the contemporary business environment. Although independent professionals outside organizations already existed in various forms (such as lawyer and accountants) since the middle of the $20^{\text {th }}$ century, their numbers have remained quite small when compared with workers (both white- and blue-collar) employed by firms. This is mainly because, as traditional economic theories of organization suggest, firms have benefited from internalizing a wide range of labor forces into the formal organizational structure and placing them in the same, fixed locations such as offices and factories to effectively manage them in a centralized manner. In other words, firms deemed it costly and risky to utilize people who are outside of the organizational boundaries and largely distributed in a wide area due to limited communication and coordination technologies available in the industrial age such as trains, cars, telegraph, fixed telephone, and mainframe computers. In consequence, firms have remained large.

However, in today's ubiquitous information environment supported by powerful and reasonably affordable computing devices and services, firms have become capable of coordinating their business processes and utilizing outside workers, particularly those who have distinct skills and expertise. They no longer have to hold a large number of permanent workers inside the organizations for the sake of centralized coordination of business processes (Malone et al. 1987). Many of the highly skilled people in firms are actually spinning out and finding their workplaces outside firms, since being free and independent can provide them with greater benefits such as gaining more reward for their work and managing their career and lives more flexibly. Some of these people are getting together and forming loosely bound partnership-based organizations such as 
consulting firms and design studios, but each of them still retains much more autonomy and freedom than professionals inside firms. Therefore, considering these shifts occurring around post-modern, mobile professionals and their impact upon contemporary business activities, we must give careful consideration to how such professionals work with organizations and how particular ICTs are utilized in their everyday work practices.

\section{A FIELD STUDY}

In order to acquire a realistic picture of actual work practices of mobile professionals, an empirical field study was conducted from April to July 2002 in Tokyo, Japan. The field study adopted the inductive qualitative research approach employing openended interviews based on an interview guide and ad hoc participant observations. In addition to the recorded interviews based the interview guide, highly contextualized data about work practices was collected immediately before, during, and after each interview session.

Tokyo was chosen as the site for this study for two primary reasons. First, the distinctive institutional background of Tokyo is particularly interesting with a work environment distinctly different from that of Western countries. The Japanese corporate system has typically been associated with three institutionalized traditions: lifetime employment, promotion by seniority, and the enterprise union system (Aoki and Dore 1996). A widely persistent, steep vertical structuring still exists, as well as administrative and corporate bureaucracy (Nakane 1983). Within such a distinctive world, almost all Japanese professionals have been employed by the government or large corporations, which led to the highly elitist internal structure of organizations. This institutional distinctiveness of the Japanese work environment could benefit us in understanding actual opportunities, problems, obstacles, and hopes that emerging professional workers are currently facing with more clarity and contrast than looking at work environments in Western contexts.

Second, Japan's unique and advanced technological environment is also critical for the choice of fieldwork location. It is widely recognized that Japan has enjoyed advanced technological innovations that resulted largely from Japanese industries' strength in research and development and manufacturing of technical devices, systems, and large infrastructures. Japan is in the middle of dramatic technological innovation and diffusion of mobile technology (Rheingold 2002). Such a unique technological environment potentially influences Japanese mobile professionals' work practices. The specific socio-technical environment in Tokyo, therefore, makes it a highly suitable setting for studying the emerging realities of mobile technology use.

The informants were selected based on the following definition of the mobile professional:

The mobile professional is a worker:

(1) who owns distinct and competitive work skills and/or knowledge;

(2) who works independently, largely freed from formal organizational constraints and rigid employment relationships; and 
(3) whose work activities are highly mobile in terms of operation, location, and interaction with the support of ICT, particularly mobile technology.

Table 1 lists the informants interviewed in this field study.

The occupation of the mobile professionals interviewed ranged widely. The largest (11) group of occupation consisted of independent consultants. There could be several reasons for this group being the largest. Independent consultants represent distinct skills and knowledge, they are independent in their work practices and can flexibly organize their work.

The second largest group (9) was entrepreneurs. Although entrepreneurs are not likely to be seen as mobile professionals, their working lives display significant characteristics common to other kinds of mobile professionals. They have a clear vision of their business and highly distinct skills and knowledge combined with a high enthusiasm aimed at making their vision materialize. In terms of high competitiveness in skills and knowledge, independent consultants and entrepreneurs present commonalities; whereas independent consultants utilize their skills and knowledge for their clients, entrepreneurs do so for their own. Entrepreneurs, too, can manage their work activities flexibly. While they usually own their office, their work activities span a wide range of areas for meetings and negotiation with various business partners. Considering these unique characteristics, entrepreneurs should also be regarded as an important group of mobile professionals. Designers (six) and journalists (four) are also distinct informant groups in this field study.

\section{FOCUS CASES}

Three focus cases of mobile professionals that proved to be particularly exemplary among all the informants are presented here. First is the case of an independent town planning consultant, which shows the high degree of mobility in terms of work sites. Second is the case of a freelance computer graphics (CG) designer, where various Internet-based tools and applications play critical roles in his highly independent but collaborative work style. Third is the case of an e-business entrepreneur, which demonstrates various consequences of the use of mobile technology in mobile professional work. Obviously, in each case, only a small portion of the entire transcript is presented here. Some descriptions drawn from ad hoc observation in the cases are also used to complement the interview data.

\subsection{Case A: Independent Town Planning Consultant}

Jun, ${ }^{1} 38$, started his independent consulting business in 2000 . His main consulting field is town planning for small-and medium-sized municipalities. He works alone with

${ }^{1}$ All names have been changed to protect privacy. 
Table 1. List of Informants

\begin{tabular}{|c|c|c|c|}
\hline No. & Job & Gender & Age \\
\hline 1 & Independent consultant & $\overline{\mathrm{M}}$ & $50 \mathrm{~s}$ \\
\hline 2 & $\begin{array}{l}\text { Corporate manager } \\
\text { (employed) }\end{array}$ & $\bar{M}$ & $50 \mathrm{~s}$ \\
\hline 3 & Entrepreneur & $\overline{\mathrm{M}}$ & $30 \mathrm{~s}$ \\
\hline 4 & Independent consultant & $\mathrm{M}$ & $30 \mathrm{~s}$ \\
\hline 5 & Independent consultant & $\bar{M}$ & $50 \mathrm{~s}$ \\
\hline 6 & $\begin{array}{l}\text { Corporate researcher } \\
\text { (employed) }\end{array}$ & $\bar{M}$ & $30 \mathrm{~s}$ \\
\hline 7 & $\begin{array}{l}\text { Corporate researcher } \\
\text { (employed) }\end{array}$ & $\bar{M}$ & $30 \mathrm{~s}$ \\
\hline 8 & Consultant (employed) & $\overline{\mathrm{F}}$ & $30 \mathrm{~s}$ \\
\hline 9 & $\begin{array}{l}\text { Marketing planner } \\
\text { (employed) }\end{array}$ & $\overline{\mathrm{M}}$ & $30 s$ \\
\hline 10 & $\begin{array}{l}\text { Marketing planner } \\
\text { (employed) }\end{array}$ & $\bar{F}$ & $30 \mathrm{~s}$ \\
\hline 11 & Consultant (employed) & $\bar{M}$ & $30 \mathrm{~s}$ \\
\hline 12 & Entrepreneur & $\mathrm{M}$ & $30 \mathrm{~s}$ \\
\hline 13 & Entrepreneur & $\bar{M}$ & $50 \mathrm{~s}$ \\
\hline 14 & $\begin{array}{l}\text { Corporate researcher } \\
\text { (employed) }\end{array}$ & $\bar{M}$ & $30 \mathrm{~s}$ \\
\hline 15 & Designer (freelance) & $\overline{\mathrm{M}}$ & $30 \mathrm{~s}$ \\
\hline 16 & Journalist (employed) & $\overline{\mathrm{M}}$ & $20 \mathrm{~s}$ \\
\hline 17 & $\begin{array}{l}\text { Marketing planner } \\
\text { (employed) }\end{array}$ & $\bar{M}$ & $30 \mathrm{~s}$ \\
\hline 18 & Designer (freelance) & $\bar{M}$ & $30 \mathrm{~s}$ \\
\hline 19 & $\begin{array}{l}\text { Corporate manager } \\
\text { (employed) }\end{array}$ & $\bar{M}$ & $\overline{40 s}$ \\
\hline 20 & Entrepreneur & $\bar{M}$ & $20 \mathrm{~s}$ \\
\hline 21 & Entrepreneur & $F$ & $20 \mathrm{~s}$ \\
\hline 22 & Designer (freelance) & $\bar{M}$ & $20 \mathrm{~s}$ \\
\hline 23 & Independent consultant & $\overline{\mathrm{M}}$ & $20 \mathrm{~s}$ \\
\hline 24 & Entrepreneur & $\bar{M}$ & $30 \mathrm{~s}$ \\
\hline 25 & Entrepreneur & $\bar{M}$ & $20 \mathrm{~s}$ \\
\hline 26 & $\begin{array}{l}\text { Corporate manager } \\
\text { (employed) }\end{array}$ & $\bar{M}$ & $30 \mathrm{~s}$ \\
\hline 27 & Designer (employed) & $\mathrm{F}$ & $30 \mathrm{~s}$ \\
\hline 28 & Journalist (employed) & $\bar{F}$ & $20 \mathrm{~s}$ \\
\hline 29 & Freelance producer & $F$ & $30 \mathrm{~s}$ \\
\hline 30 & Consultant (employed) & $\bar{M}$ & $30 \mathrm{~s}$ \\
\hline 31 & $\begin{array}{l}\text { Corporate researcher } \\
\text { (employed) }\end{array}$ & $\bar{M}$ & $30 \mathrm{~s}$ \\
\hline
\end{tabular}

\begin{tabular}{|c|c|c|c|}
\hline No. & Job & Gender & Age \\
\hline 32 & $\begin{array}{l}\text { Corporate manager } \\
\text { (employed) }\end{array}$ & $\overline{\mathrm{F}}$ & $40 \mathrm{~s}$ \\
\hline 33 & Consultant (employed) & $\mathrm{F}$ & $20 \mathrm{~s}$ \\
\hline 34 & Architect & $\bar{M}$ & $40 \mathrm{~s}$ \\
\hline 35 & Independent consultant & $\bar{M}$ & $30 \mathrm{~s}$ \\
\hline 36 & $\begin{array}{l}\text { Sales coordinator } \\
\text { (employed) }\end{array}$ & $\bar{M}$ & $30 \mathrm{~s}$ \\
\hline 37 & Consultant (employed) & $\bar{M}$ & $30 \mathrm{~s}$ \\
\hline 38 & $\begin{array}{l}\begin{array}{l}\text { Marketing planner } \\
\text { (employed) }\end{array} \\
\text { (emplo }\end{array}$ & $\bar{M}$ & $30 \mathrm{~s}$ \\
\hline 39 & Entrepreneur & $\bar{F}$ & $50 \mathrm{~s}$ \\
\hline 40 & Independent consultant & $\bar{M}$ & $50 \mathrm{~s}$ \\
\hline 41 & Designer (freelance) & $\bar{M}$ & $50 \mathrm{~s}$ \\
\hline 42 & Journalist & $\mathrm{M}$ & $30 \mathrm{~s}$ \\
\hline 43 & Journalist & $\mathrm{M}$ & $30 \mathrm{~s}$ \\
\hline 44 & $\begin{array}{l}\text { Sales coordinator } \\
\text { (employed) }\end{array}$ & $\bar{M}$ & $20 \mathrm{~s}$ \\
\hline 45 & Independent consultant & $\bar{M}$ & $50 \mathrm{~s}$ \\
\hline 46 & $\begin{array}{l}\text { Marketing planner } \\
\text { (employed) }\end{array}$ & $\bar{M}$ & $30 \mathrm{~s}$ \\
\hline 47 & Independent consultant & $\bar{M}$ & $30 \mathrm{~s}$ \\
\hline 48 & Entrepreneur & $\bar{M}$ & $30 \mathrm{~s}$ \\
\hline 49 & $\begin{array}{l}\text { Sales coordinator } \\
\text { (employed) }\end{array}$ & $\bar{M}$ & $30 \mathrm{~s}$ \\
\hline 50 & Independent consultant & $\bar{M}$ & $50 \mathrm{~s}$ \\
\hline 51 & Independent consultant & $\bar{M}$ & $30 \mathrm{~s}$ \\
\hline 52 & Independent consultant & $\mathrm{M}$ & $50 \mathrm{~s}$ \\
\hline 53 & Designer (freelance) & $\mathrm{M}$ & $50 \mathrm{~s}$ \\
\hline 54 & Consultant (employed) & $\bar{M}$ & $40 \mathrm{~s}$ \\
\hline 55 & Consultant (employed) & $\mathrm{M}$ & $40 \mathrm{~s}$ \\
\hline 56 & $\begin{array}{l}\text { Marketing planner } \\
\text { (employed) }\end{array}$ & $\bar{M}$ & $30 \mathrm{~s}$ \\
\hline 57 & $\begin{array}{l}\text { Marketing planner } \\
\text { (employed) }\end{array}$ & $\bar{M}$ & $30 \mathrm{~s}$ \\
\hline 58 & $\begin{array}{l}\text { Corporate researcher } \\
\text { (employed) }\end{array}$ & $\overline{\mathrm{M}}$ & $20 \mathrm{~s}$ \\
\hline 59 & $\begin{array}{l}\text { Corporate researcher } \\
\text { (employed) }\end{array}$ & $\overline{\mathrm{M}}$ & $20 \mathrm{~s}$ \\
\hline 60 & $\begin{array}{l}\text { Sales coordinator } \\
\text { (employed) }\end{array}$ & $\bar{M}$ & $20 \mathrm{~s}$ \\
\hline 61 & Academic researcher & $\mathrm{M}$ & $30 \mathrm{~s}$ \\
\hline 62 & Academic researcher & $\mathrm{M}$ & $30 \mathrm{~s}$ \\
\hline
\end{tabular}


no employees but collaborates with many people including other consultants and developers. The majority of his current clients are small- and medium-sized municipalities, mainly in rural areas hundreds miles away from big cities such as Tokyo and Osaka.

He finds the high degree of mobility in his work activities the most conspicuous advantage as a professional worker. Town planning projects typically require the project members to see the actual site in which a certain plan is to be implemented. He also argues that visiting the site and seeing it with his own eyes is crucial for the town planning business, since observation of the site offers invaluable data and insights for the project. Acquiring a Subnote $\mathrm{PC}$ and a mobile phone changed his way of working dramatically. With his mobile phone, he was able to easily contact and be contacted by his clients and coworkers virtually (not completely) anytime, anywhere. The Subnote $\mathrm{PC}$ connected with the mobile phone provided him with almost the same PC environment during business trips and site observation.

His work practices clearly show two basic patterns of geographic movement. First is the long-distance travel. He follows a working style where he can spend a considerable amount of time at the actual sites where his clients' problem issues reside. Most of his clients are local governments in areas far away from Tokyo. Therefore, it is inevitable that he frequently travels hundreds of miles for a visit and explores the sites physically. Second is the intensive local travel. He moves around the Tokyo area intensively to meet his clients and other members of the projects, since meeting those people fact-to-face is extremely important for his business. In such local travel, he usually uses underground trains and taxis, or he walks. Just like moving around Tokyo, he also travels intensively in and across the local areas when visiting the clients' sites.

\subsection{Case B: Freelance Computer Graphics Designer}

Yoshi, 35, is working as a freelance CG designer in Tokyo. He uses a room in his home in central Tokyo as his workspace where he does almost all of his design work. After graduating from a university with a degree in graphic design, he got a job in one of the biggest design firms in Japan. Having worked as a graphic designer for 8 years in the firm, he became freelancer 5 years ago. He is an expert of on three-dimensional CG (3D-CG) design, but most of his work revenue comes from projects relating to Web site design and coding. He gains most of his revenue from Web site design work for music production companies.

Due to the nature of CG design, he spends a considerable amount of time in front of the computers in this room. In this regard, he is mostly a static home-worker. However, he engages in intense interaction with people outside by actively using the Internet technologies. Particularly interesting is that his corporeal movement is largely static, sitting in a room for a long period of time, but the range of his interaction with other people through the Internet spans the globe and the patterns are significantly intense and diverse.

Even though the intense interaction with various people through the Internet greatly helps Yoshi gain access to the latest information about hardware and software, he is still faced with a considerable lack of physical human interaction. In this regard, he has a 
special place. In 1997, Yoshi received the highly respected CG design award founded by a large entertainment company, one of the most reputable and widely known CG design awards in Japan. This company has established a special design studio in one of their office buildings in central Tokyo exclusively for the winners and finalists of the award. For Yoshi, the special design studio seems to function as a $B a$ (Nonaka and Konno 1998), a place where people can share a distinct context of working and exchange a variety of tangible and intangible goods. Such a place can provide people with broad opportunities for "real" human interaction, which facilitate exchange of valid information concerning new clients and jobs. Furthermore, the studio is also a place for collaboration. Since each of the designers coming to the studio has a distinct background and expertise of design, they can easily find each other as complementary in their design work.

\subsection{Case C: E-Business Entrepreneur}

Hiro, 35, is CEO of a small software company. After being involved in the Internet service provider (ISP) business for a few years, he founded the company in 1998. The company primarily develops entertainment software and digital content such as networkbased games on the Internet, a music-composing tool for PCs, and, more recently, various tools and network content for Internet-enabled mobile phone services such as the NTT DoCoMo i-mode platform

In contrast to the two previous cases, Hiro is subject to much more intense and dynamic interaction with other people. Whereas Jun and Yoshi primarily work alone and only interact with a limited number of clients and members of projects at one time, Hiro has 20 members of staff in his company. Moreover, he is involved in constantly changing business situations where he has to interact with a diverse range of current and prospective stakeholders. In order to cope with this, he utilizes the combination of email and mobile phone technologies as the primary means of managing his interaction: He forwards all incoming e-mail to his Internet-enabled mobile phone. In fact, during the interview, his mobile phone notified him about received e-mail several times, and he checked them immediately. This emphasized the fact that he was engaged in a constant flow of multiple interaction threads. For him, it proved impossible at one particular time to focus on a single interaction at hand and to exclude others. He needed to juggle multiple interaction threads by effectively using technology.

\section{FLUID ORGANIZING OF WORK}

As clearly shown in the three focus cases above, mobile professional work is in rapidly changing work settings and in a constant flux of interaction with various stakeholders. In the ubiquitous information environment where people can interact with others by using such emerging technologies as e-mail, Web services, mobile phones, and PDAs, relational disposition of human interaction is becoming ambiguous and transitory. In particular, the dynamic and heterogeneous work practices of mobile professionals inherently involve the capacity of boundary formation at various levels of organization. 
These findings offer us a new perspective on work practice as a fluid (Mol and Law 1994; Urry 2000). A fluid is "a world of mixtures" and "variation without boundaries and transformation without discontinuity" (Mol and Law 1994,p. 600). A fluid world ensured by multiple mobilization of interaction can be characterized as "the remarkably uneven and fragmented flows of people, information, objects, money, images and risks across regions in strikingly faster and unpredictable shapes" (Urry 2000, p. 38). This is clearly the world of the contemporary mobile professional work. As the fieldwork results show, mobile professionals get their jobs done not only in formal offices but at various sites such as home, clients' offices, hotels, moving vehicles, and so on; anywhere can be their office. With the powerful support of ICTs, their work practices permeate across various regions of work (projects, teams, organizations, etc.) and networks (private and public, formal and informal, etc.). The fluid nature of work practice cannot be fully captured from static perspectives, since it always transforms the work context. Mobile professionals' work practices are always in transition, extensively moving around, participating in several different projects, and interacting with diverse stakeholders.

Contemporary businesses, especially in media, entertainment, and ICT-related areas, increasingly utilize nontraditional labor forces such as contract-based workers, people from staffing service companies, various kinds of freelancers, and contract-based technicians (Barker and Christensen 1998; Cappelli 1999). Furthermore, companies are actively adopting newly developed, flexible organizational practices such as task forces, project-based teams, and virtual teams, which typically include various "outside" professional members such as consultants, designers, and planners (Snow et al. 1999; Townsend et al. 1998). Given these emerging company practices, it seems that an organization as a distinct unit of operation and hence of analysis is far from self-evident or well-defined, since the unity of today's organization in turbulent business environments, particularly knowledge-intensive industries, is predicated less and less on stable organizational structure, constant and well-defined business processes, or long-lasting membership of the staff.

Mobile professionals are one of the most radical groups of workers whose work activities deconstruct the traditional sense of unity of organizations. Mobile professionals are keen to liberate themselves from organizational structures, processes, and conventions that are likely to hamper their knowledge-intensive, autonomous ways of working. In the case of the independent consultant discussed above, for example, Jun should be seen as an outsider from a traditional point of view, as he does not have a formal employment relationship with any organization. However, from the project members' point of view, he should be seen as an insider in the sense that due to his distinct skills and knowledge, his work practices are tightly linked to the client's business processes and hence competitiveness. Acting as knowledge brokers, mobile professionals constantly straddle boundaries at various levels and form new boundaries of a group of practitioners, or a community of practice (Wenger 1998), through their fluid work practices over time.

Given such fluid organizing of work, the traditional image of organization might require reconsideration. When considering the fact that mobile professionals' work practices typically cut through and reformulate boundaries at various levels over time, the distinction between organization and environment and between inside and outside 
becomes vague. Many have already proposed the network-based view of organization (e.g., Castells 1996; Jarvenpaa and Ives 1994; Powell 1989; Rockart and Short 1991; Snow et al. 1992; Van Alstyne 1997). Largely supported by the development and diffusion of ICTs in general and the Internet in particular, today's organizations have become capable of coordinating business operations and processes by directly reaching to and connecting with a variety of players in the market such as foreign business partners, suppliers of raw materials and parts, famous designers in the world, and their own customers. Castells (1996) describes this transformation by stating that "networks constitute the new social morphology of our societies, and the diffusion of networking logic substantially modifies the operation and outcomes in processes of production, experience, power, and culture" (p. 469). Powell (1989) argues that the networked forms of organization can be an alternative to the transactions of markets and the hierarchical governance structures of firms in some industrial sectors. However, despite the implications of those theories for our understanding of contemporary organizations, it appears that their theorization is still largely static, specifically because of the network metaphor. The network metaphor is typically described by the assemblage of interconnected nodes, hubs, and spokes. While this metaphorical approach is particularly useful for explaining complex relationships between the organization and its diverse stakeholders, it seems to be implicitly but firmly predicated on static, snapshot depictions of the ongoing operations and processes that dynamically constitute and reconstitute emergent relationships among the stakeholders.

Imai and Kaneko (1988) point out the fundamental difference between the traditional image of networks and the one in actual organizational contexts (see Figure 1). Through their investigation of Japanese manufacturing and other industries, they insist that the network organization in actual organizational settings is

constructed not through individuals' activities as discrete functional elements in the organization but through each individual's personal and spontaneous activities that create self-organizing relationships amongst the members, redefine boundaries between "self" and "others," and then produce dynamic and diverse contexts in which real innovations emerge (p. 149; translated by the author).

This view greatly resonates with the fluid metaphor by Mol and Law (1994). As opposed to computer networks, the configuration of social networks is always in a dynamic transformation. Relationships and boundaries in social networks in work settings can never be fixed but are iteratively produced and reproduced through the stakeholders' work practices, which in turn create work contexts in which they interact with each other. This view does not deny the existence of relationships and boundaries in organizational settings; however, it requires us to pay specific attention to the emergent aspects of ongoing formation of the relationships and boundaries in actual work contexts.

Some scholars have discussed such a fluid perspective of work and organization. Morgan's (1997) comprehensive review of various images of organization provides a useful overview. Along with many other images of organization such as machines, organisms, brains, cultures, political systems, psychic prisons, and instruments of domination, he offers a distinct image of organization as flux and transformation. By 
The traditional image of networks

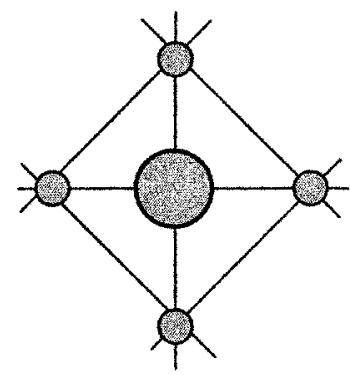

Networks in actual organizational contexts

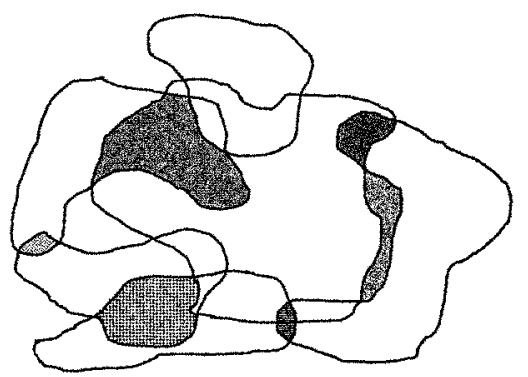

Figure 1. Comparison between the Traditional and Actual Views on Networks (Adapted from Imai and Kaneko 1988)

applying autopoiesis theory (Maturana and Varela 1980, 1992), Morgan explains that organizations can be seen as constant flow and change that can hardly be captured from a static, external observer's view. From this fluid perspective, the distinction between organization and environment is just a product of external observation, insisting that relations with any environment are internally determined and boundaries are continuously produced and reproduced through continuous enactment of self-referencing acts.

Ciborra's (1996) discussion of "the platform organization" is related more closely to fluid organizing of work discussed in this paper. He explains that the platform organization is

[A] virtual organizing scheme, collectively shared and reproduced in action by a pool of human resources, where structure and potential for strategic action tend to coincidence in highly circumstantial ways, depending upon the transitory contingencies of the market, the technology and the competitors' moves (p. 115).

More succinctly, the platform organization, he argues, can be characterized by "fragmentation, fuzziness and displacement" (p. 116). Through his detailed case study of Olivetti, a leading European computer company at the time of his study, the organization sometimes markedly exhibited organizational features far from the traditional images of specific organizational structure, authority lines, and communication flows. It is full of chaotic events, contingencies, and surprises, which in turn produce new organizational configuration. While Mintzberg (1983) proposes a similar form of organization, adhocracy, characterized as organic, flexible, nonhierarchical and highly informal, Ciborra's platform organization places much more emphasis upon transformation and improvisation in and around the organization. Although Ciborra's focus is mainly on internal events of the company, his study clearly indicates that an organization can be perceived as a fluid. 
As clearly seen above, a fluid pattern of organizing work practices has been discussed sporadically in the history of study on the relation between organization and ICT. It can be argued that in the light of today's emerging ubiquitous information environment, it is more and more important to address a fluid pattern of organizing work practices in relation to ICTs in general and mobile and wireless technologies in particular. As we have seen in the field study of mobile professionals in Japan, mobile professional work would be one of the most conspicuous cases that vividly present various consequences of fluid organizing of work. Mobile professionals reconstruct organizational settings and boundaries through their fluid work practices largely supported by their active utilization of ICTs. Such fluid work practices could not be fully appreciated through the traditional organizational perspectives predicated on static understanding of work and organization.

\section{CONCLUDING REMARKS}

This paper discusses the emerging pattern of work in today's ubiquitous information environment through an empirical field study of mobile professionals. The fieldwork results show that the work practices of mobile professionals should be best appreciated through a fluid perspective capturing the dynamic and heterogeneous nature of work practices. Mobile professionals' fluid organizing of work is heavily based on and supported by their active utilization of ICTs for interaction and collaboration. Furthermore, the fieldwork results put into question the traditional understanding of organization predicated on the a priori assumption of organizational boundaries.

It should be noted, however, that such a fluid perspective of work and organization cannot be applied to all of the realities of today's organizational phenomena. For instance, mobile professionals currently account for a fraction of the entire workforce even in urban areas of developed countries. Furthermore, industries that actively utilize mobile professionals as a competitive and flexible workforce are still quite limited, mainly to knowledge-intensive and/or ICT-related industries. Therefore, the fluid nature of work practice might appear in few occasions and in organizations in a small number of industries.

Nevertheless, it would be fair to say that a fluid perspective of work and organization will be more and more important in the age of the ubiquitous information environment. It is widely acknowledged that knowledge has become a critical resource for competitiveness in a wide range of industries. As many argue, dealing with knowledge in organizational contexts is always an issue spreading across boundaries between teams and between organizations, and the configuration of such boundaries are constantly transformed over time through face-to-face and mediated interaction among diverse stakeholders (Ciborra and Andreu 2001; Knights et al. 1993). In such dynamic intra-, inter-, and transorganizational contexts, it is important to address actual work practices of people in and around organizations not from a rigid and static perspective but from a fluid perspective that can shed light upon the ever-changing nature of organizational knowledge. Individuals, teams, organizations, institutions - all are being faced with the upheaval of existing work settings, structures, and conditions, shifting from relatively stable and static states to dynamic and constant transformation. In order 
to address these fluid social realities in the ubiquitous information environment, our perspective also has to be dynamic and flexible. The perspective of fluid organizing of work can be one such distinct analytical lenses.

\section{REFERENCES}

Aoki, M., and Dore, R. The Japanese Firm: The Sources of Competitive Strength, Oxford, UK: Oxford University Press, 1996.

Barker, K., and Christensen, K. "Controversy and Challenges Raised by Contingent Work Arrangement," in Contingent Work: American Employment in Transition, K. Barker and K. Christensen (Eds.), Ithaca, NY: ILR Press, 1998, pp. 1-20.

Cappelli, P. The New Deal at Work: Managing the Market-driven Workforce, Boston: Harvard Business School Press, 1999.

Castells, M. The Rise of the Network Society, Malden, MA: Blackwell, 1996.

Ciborra, C. U. "The Platform Organization: Recombining Strategies, Structures, and Surprises," Organization Science (7:2), 1996, pp. 103-118.

Ciborra, C. U., and Andreu, R. "Sharing Knowledge Across Boundaries," Journal of Information Technology (16:2), 1996, pp. 73-81.

Imai, K., and Kaneko, I. Nettowaku Soshikiron (The Theory of Network Organizations) (in Japanese), Tokyo: Iwanami, 1988.

Jarvenpaa, S. L., and Ives, B. "The Global Network Organization of the Future: Information Management Opportunities and Challenges," Journal of Management Information Systems (10:4), 1994, pp. 25-57.

Knights, D., Murray, F., and Willmott, H. "Networking as Knowledge Work: A Study of Strategic Interorganizational Development in the Financial Services Industry," Journal of Management Studies (30:6), 1993, pp. 975-995.

Malone, T. W., and Laubacher, R. J. "The Dawn of the E-Lance Economy," Harvard Business Review (76:5), September-October 1998, pp. 145-153.

Malone, T. W., Yates, J., and Benjamin, R. I. "Electronic Markets and Electronic Hierarchies," Communications of the $A C M(30: 6), 1987$, pp. 484-497.

Maturana, H. R., and Varela, F. J. Autopoiesis and Cognition: The Realization of the Living, Dordrecht: Reidel, 1980.

Maturana, H. R., and Varela, F. J. The Tree of Knowledge: The Biological Roots of Human Understanding (Revised Edition), Boston: Shambhala, 1992.

Meager, N. "The Characteristics of the Self-employed: Some Anglo-German Comparisons," in The New Entrepreneurs, P. Leighton and A. Felstead (Eds.), London: Kogan Page, 1992, pp. 69-99.

Mintzberg, H. Structure in Fives: Designing Effective Organizations, Englewood Cliffs, NJ: Prentice-Hall, 1983.

Mol, A., and Law, J. "Regions, Networks and Fluids: Anaemia and Social Topology," Social Studies of Science (24), 1994, pp. 641-671.

Morgan, G. Images of Organization. ( ${ }^{\text {nd }}$ Edition), Thousand Oaks, CA: Sage Publications, 1997

Nakane, C. Japanese Society, Middlesex, UK: Penguin, 1983.

Nonaka, I., and Konno, N. "The Concept of 'Ba': Building a Foundation for Knowledge Creation," California Management Review (40:3), 1998, pp. 40-54.

Powell, W. W. "Neither Market Nor Hierarchy: Network Forms of Organization," in Research in Organizational Behavior Vol. 12., B. M. Staw and L. L. Cummings (Eds.), Greenwich, CT: JAI Press, 1989, pp. 295-336. 
Rheingold, H. Smart Mobs: The Next Social Revolution, Cambridge, MA: Perseus Publishing, 2002.

Rockart, J., and Short, J. "The Networked Organization and the Management of Interdependence," in The Corporations of the 1990s: IT and Organizational Transformation, M. S. Scott-Morton (Ed.), Oxford, UK: Oxford University Press, 1991, pp. 189-216.

Schön, D. A. The Reflective Practitioner: How Professionals Think in Action, New York: Basic Books, 1983.

Segal, L. M., and Sullivan, D. G. "The Growth of Temporary Services Work," Journal of Economics Perspectives (11:2), 1997, pp. 117-136.

Segal, L. M., and Sullivan, D. G. "The Temporary Labor Force," Economics Perspectives (12:2), 1995, pp. 2-19.

Snow, C. C., Lipnack, J., and Stamps, J. "The Virtual Organization: Promises and Payoffs, Large and Small," in Trends in Organizational Behavior: Vol. 6. The Virtual Organization, C. L. Cooper and D. M. Rousseau (Eds.), Chichester, UK: John Wiley \& Sons, 1999, pp. 15-30.

Snow, C. C., Miles, R. E., and Coleman, H. J. "Managing $21^{\text {st }}$ Century Network Organizations," Organizational Dynamics (20:3), 1992, pp. 5-20.

Townsend, A. M., DeMarie, S. M., and Hendrickson, A. R. "Virtual Teams: Technology and the Workplace of the Future," The Academy of Management Executive (12:3), 1998, pp. 1729.

Urry, J. "Mobile Sociology," British Journal of Sociology (51:1), 2000, pp. 185-203.

Van Alstyne, M. V. "The State of Network Organization: A Survey in Three Frameworks," Journal of Organizational Computing (7:3), 1997, pp. 83-151.

Wenger, E. Communities of Practice: Learning, Meaning, and Identity, Cambridge, UK: Cambridge University Press, 1998.

Whalley, P., and Barley, S. R. "Technical Work in the Division of Labor: Stalking the Wily Anomaly," in Between Craft and Science: Technical Work in U.S. Settings, S. R. Barley and J. E. Orr (Eds.), Ithaca, NY: Cornell University Press, 1997, pp. 23-52.

\section{ABOUT THE AUTHOR}

Masao Kakihara is an assistant professor at the School of Business Administration, Kwansei Gakuin University, Japan. He holds a B.Econ. From Kwansei Gakuin University and both an M.Sc. and a Ph.D. in Information Systems from the London School of Economics and Political Science. Prior to his postgraduate studies, he worked for four years as a corporate strategy consultant in Tokyo. His research concerns ICT-enabled work practices and mobile professional workers and those organizational consequences. His current research project looks at how various professional workers in the music industry collaborate with each other in their music production practices. Masao can be reached at kakihara@kwansei.ac.jp. 